veloping-land situation, this book will serve as a major contribution-if not the last word on the subject-for the foreseeable future.

EDWARD D. Wynot, JR.

Florida State University

\title{
DIE ANFÄNGE DER TSCHECHISCHEN ERNEUERUNG UND DAS DEUTSCHE GEISTESLEBEN (1740-1800). By Walter Schamschula. Munich: Wilhelm Fink Verlag, 1973. 338 pp. DM 68, paper.
}

The German National Socialist historiography, with its relentless emphasis on the German mission in Eastern Europe, brought into disrepute the study of German influences in Eastern Europe, no matter how real the influence or how legitimate the study. After 1945 a whole generation of younger German historians shied away from the subject-a subject that is extremely sensitive in the best of times. In this sense, Schamschula's volume is something of an act of courage, and he treads the ground carefully. He avoids any formulations that might have a Kulturträger ring. His monograph deals with the German influences on the Czech national awakening, but the very title of the volume eschews any terminology that might prejudge the case: it does not speak of influence but merely juxtaposes the "Czech revival" and the "German intellectual life." The German influence on Czech nationalism is of course a fact of life, but the author places that influence in a wider European context. This is one of the true merits of his work.

The root question, according to him, is not how the Czech revival came about but how modern European nationalism developed. His answer is that the Czech revival was part of a European movement that originated in Britain and France and traveled across the Low Countries, Germany, and Italy into the Czech regions. In this schema, the Germans were only a link-admittedly a vital one-in a chain. Nor does the author see the Czech revival, or any nation's revival, simply as the result of external influences. He rejects the "tedious" controversies over what particular factors may have triggered a nation's revival and resolves the issue by distinguishing between two elements of a revival-"substance" and "impulse." The substance is a nation's inner force, the sum of its historic traditions, values, and assets. The impulse comes from the outside, and it stimulates and quickens the development of the "substance." This is a helpful design and well worth being pondered by other specialists in the field. The body of the volume is divided into three sections: history, language, and literature. This gives Schamschula's work an interdisciplinary character and should attract a correspondingly wide audience. Each one of the three areas is treated thoroughly and leaves the reviewer little to quarrel with.

Stanley Z. Pech

University of British Columbia

DIE TSCHECHOSLOWAKISCHE HUSSITISCHE KIRCHE. By Rudolf Urban. Marburger Ostforschungen, vol. 34. Marburg/Lahn: J. G. HerderInstitut, 1973. viii, 327 pp. Paper.

This definitive work on an interesting and important phenomenon in modern church history is an excellent piece of research based on the original sources and an exten- 